УДК 347.643 .8

DOI https://doi.org/10.32849/2663-5313/2019.12.06

\title{
Оксана Козак,
}

аспірант Науково-дослідного інституту приватного права і підприємництва

імені академіка Ф. Г. Бурчака

Національної академії правових наук України

\section{ОСОБЛИВОСТІ ВИКОНАННЯ ЗОБОВ'ЯЗАНЬ ЗА ДОГОВОРОМ ПРО ВЛАШТУВАННЯ ДІТЕЙ-СИРІТ ТА ДІТЕЙ, ПОЗБАВЛЕНИХ БАТЬКІВСЬКОГО ПІКЛУВАННЯ, У ПРИЙОМНУ СІМ'Ю}

у статті акиентовано увагу на особливостях виконання зобов'язань за договором про влаштування дітей-сиріт та дітей, позбавлених батьківського піклування, у прийомну сім'ю. Наголошується, що за иим договором надаються послуги такого характеру, в яких прийомні батьки не в змозі одразу визначитися щодо можливості чи, навпаки, неможливості досягнення необхідного виховного результату. Більше того, можливість досягнення позитивного для дитини результату вимагає виконання зустрічних дій з боку як прийомних батьків, так $і$ замовника послуги та самої дитини, що ще раз свідчить про складність досліджуваних правовідносин. Для досліджуваного договору виконання полягає у постійній участі: а) прийомних батьків у вихованні, піклуванні, спілкуванні, навчанні тощо з прийомними дітьми та органом виконавчої влади; б) органу виконавчої влади, який здійснює сочіальне супроводження прийомної сім'ї.

Особливість виконання зобов'язань за договором про влаштування дітей-сиріт та дітей, позбавлених батьківського піклування, у прийомну сім'ю відображається у таких елементах, як: 1) суб'єкти виконання - замовник (орган виконавчої влади) і виконавець (прийомні батьки); 2) предмет виконання (дї̈ з надання відповідної послуги та ї̈ оплати); 3) строк виконання (до досягнення 18-річного віку, а в разі навчання у професійно-технічних, вищих навчальних закладах I-IV рівнів акредитації до його закінчення); 4) місие виконання (місие проживання прийомних батьків); 5) спосіб виконання (пов'язаний з педагогічними, освітніми, медичними здібностями прийомних батьків).

Специфіка договору про влаштування дітей-сиріт та дітей, позбавлених батьківського піклування, у прийомну сім'ю полягає у закріпленні законодавчої вимоги до прийомних батьків надати послугу такого характеру особисто. Особистість прийомних батьків має істотне значення, тому до таких відносин застосовуються положення ч. $1 \mathrm{~cm} .902$ ЦК України. Особливість виконання досліджуваного договору відображається також $і$ в тому, що послуга надається не безпосередньо замовнику, а визначеній ним третій особі (дитині-сироті чи дитині, позбавленій батьківського піклування).

Належне виконання умов зі влаштування дітей-сиріт та дітей, позбавлених батьківського піклування, у прийомну сім'ю щодо предмета відображається у наданні виховної послуги з дотриманням відповідних правил щодо проживання, освіти, харчування, відпочинку, усиновлення тощо дитини, а щодо строку - у закріпленні прямої вказівки на строк договору у спещіальному нормативно-правовому акті та неможливості дострокового надання послуги.

Ключові слова: договір, прийомна дитина, прийомна сім'я, прийомні батьки, виконання умов договору, суб'єкти виконання, предмет виконання, строк виконання, спосіб виконання, місце виконання.

Постановка проблеми. Аналізуючи особливості виконання сторонами зобов'язань за договором про влаштування дітей-сиріт та дітей, позбавлених батьківського піклування, у прийомну сім'ю, доцільно зазначити, що за цим договором надаються послуги такого характеру, в яких прийомні батьки не в змозі одразу визначитися щодо можливості чи, навпаки, неможливості досягнення необхідного виховного результату. Більше того, можливість досягнення позитивного для дитини результату вимагає виконання зустрічних дій з боку як прийомних батьків, так і замовника послуги та самої дитини, що ще раз свідчить про складність досліджуваних правовідносин.

Як і до будь-яких інших договорів, закріплених у Сімейному кодексі України 
(далі - СК України), до досліджуваного нами договору немає встановлених вимог щодо його належного виконання. Із цього можемо зробити висновок про застосування до цих правовідносин загальних положень гл. 48 Цивільного кодексу України «Виконання зобов'язань» (далі - ЦК України), основоположним принципом яких є виконання зобов'язання належним чином, відповідно до умов договору та вимог актів цивільного законодавства, а за відсутності таких вимог - відповідно до звичаїв ділового обороту або інших вимог, що звичайно ставляться.

Зважаючи на те, що договір про влаштування дітей-сиріт та дітей, позбавлених батьківського піклування, у прийомну сім'ю має на меті створення оптимальних умов життя і діяльності цих дітей, сприяння їх моральному і фізичному розвитку, підготовці до самостійного життя, зазначеній меті підпорядкований і зміст договору, де закріплено суб'єктивні права та юридичні обов'язки його сторін. Для досліджуваного договору виконання полягає у постійній участі: а) прийомних батьків у вихованні, піклуванні, спілкуванні, навчанні тощо з прийомними дітьми та органом виконавчої влади; б) органу виконавчої влади, який здійснює соціальний супровід прийомної сім’ї. Отже, вчинення дій щодо виконання умов договору про влаштування дітей-сиріт та дітей, позбавлених батьківського піклування, у прийомну сім'ю $€$ односторонньо зобов'язуючими правочинами, якими можуть бути визнані тільки правомірні дії.

Відповідно, під виконанням договірних зобов'язань зі влаштування дітей-сиріт та дітей, позбавлених батьківського піклування, у прийомну сім'ю слід розуміти сукупність фактичних або юридичних дій (у певних випадках - утримання від дії) сторін зобов'язання, спрямованих на реалізацію (здійснення) передбачених договором або законом їхніх суб'єктивних прав і обов'язків задля досягнення економічної і юридичної мети зобов'язання.

Мета статті - розкрити особливості виконання зобов'язань за договором про влаштування дітей-сиріт та дітей, позбавлених батьківського піклування, у прийомну сім'ю.

Виклад основного матеріалу. Переходячи до аналізу елементів виконання договору про влаштування дітей-сиріт та дітей, позбавлених батьківського піклування, у прийомну сім'ю, насамперед зазначимо, що для розуміння виконання договору слід виділити найбільш суттєві елементи, дотримання яких призводить до припинення юридичного зв'язку між сторонами, а саме: 1) суб'єкти виконання - замовник (орган виконавчої влади) і виконавець (прийомні батьки); 2) предмет виконання (дії з надання відповідної послуг та їх оплата); 3) строк виконання (до досягнення 18-річного віку, а в разі навчання у професійно-технічних, вищих навчальних закладах I-IV рівнів акредитації - до його закінчення); 4) місце виконання (як правило, місце проживання прийомних батьків); 5) спосіб виконання (багато в чому пов'язаний з педагогічними, освітніми, медичними здібностями прийомних батьків).

Отже, серед усіх вищенаведених елементів виконання зобов'язань за договором про влаштування дітей-сиріт та дітей, позбавлених батьківського піклування, у прийомну сім'ю такий елемент, як виконання договірних умов належними сторонами, є надзвичайно важливим. Так, для дитини важливо виховуватись тими людьми, до яких вона звикла, сприймає їх як рідних, проводить 3 ними час. Відповідно, особливість виконання цього договору пов'язана із закріпленням законодавчої вимоги до прийомних батьків надати послугу такого характеру особисто. У зв'язку з цим особистість прийомних батьків має істотне значення, тому до таких відносин застосовуються положення ч. 1 ст. 902 ЦК України. Особливість виконання досліджуваного договору відображається також і в тому, що послуга надається не безпосередньо замовнику, а визначеній ним третій особі (дитині-сироті чи дитині, позбавленій батьківського піклування). Таким чином, належне виконання насамперед відображається у виконанні належними сторонами договірних зобов'язань. Звідси випливає й специфіка договору про влаштування дітей-сиріт та дітей, позбавлених батьківського піклування, у прийомну сім'ю.

Наступним елементом належного виконання договорів про надання послуг є предмет виконання. 3 цього приводу варто сказати про розмежування на доктринальному рівні понять «предмет зобов'язання» і «предмет виконання зобов'язання» як нетотожних. Так, у юридичній літературі наголошується на доцільності розуміння під предметом виконання дії виконавця щодо надання відповідної послуги і замовника - щодо їх оплати [1, с. 236], а під предметом зобов'язання - безпосередньо саму послугу [2, с. 316]. Екстраполюючи наведені висновки у досліджувані нами договірні зобов'язання, слід наголосити, що предметом зобов'язання є соціальна послуга зі влаштування дитини у свою сім'ю, а предметом виконання - сукупність дій прийомних батьків, спрямованих на задоволення потреб прийомної дитини як фактичного, так і юридич- 
ного характеру. Тобто виконання зобов'язання шляхом надання послуги, що відображається у вчиненні відповідних дій прийомними батьками та їх систематичному фінансуванні з боку замовника, $є$ важливим етапом виконання, адже інакше не буде досягнуто основної мети зобов'язання - задоволення потреб прийомної дитини як фактичного, так і юридичного характеру. Належне виконання умов зі влаштування дітей-сиріт та дітей, позбавлених батьківського піклування, у прийомну сім’ю щодо предмета відображається у наданні виховної послуги з дотриманням відповідних правил щодо проживання, освіти, харчування, відпочинку, усиновлення тощо дитини. Зазначене підтверджується висловленою М.Д. Пленюк тезою, що належне виконання цивільного договору є юридичним фактом, який за характером спричинених наслідків є правоприпиняючим, оскільки належне виконання договірного зобов'язання припиняє цивільні відносини досягненням певного (очікуваного) результату [3, с. 85].

Аналізуючи такий елемент виконання договору про влаштування дітей-сиріт та дітей, позбавлених батьківського піклування, у прийомну сім'ю, як спосіб виконання, слід зазначити, що ні СК, ні ЦК України не містить загального правила, яке б визначало спосіб виконання договірного зобов'язання, тобто розкривало характер (послідовність) тих дій, які є змістом цього поняття. Водночас спосіб виконання зобов'язання перебуває у прямій залежності від предмета виконання [4, с. 649]. В юридичній літературі саме через характер дій (порядок, процедуру, послідовність їх вчинення) розкривається спосіб виконання зобов'язання [5, с. 588], що завжди залежить від специфіки окремих зобов'язань [6, с. 94].

Зважаючи на вищенаведене, доцільно наголосити, що зобов'язання як прийомних батьків, так і органу виконавчої влади виконуються у специфічний спосіб, адже $€$ тривалими в часі. Так, уповноважений на прийняття рішення про створення прийомної сім’ї орган виконавчої влади постійно повинен забезпечувати: 1) соціальний супровід прийомної сім'ї шляхом закріплення за нею соціального працівника; 2) щорічне безоплатне медичне обстеження дітей; 3) щомісячні виплати державної соціальної допомоги на дітей та грошове забезпечення; 4) відрахування страхових внесків на загальнообов'язкове державне пенсійне страхування тощо. Натомість прийомні батьки постійно повинні: 1) забезпечувати дитину повноцінним харчуванням, вихованням, навчанням за рахунок щомісячної державної соціальної допомоги на дитину; 2) всіляко сприяти обов'язковому щоріч- ному медичному обстеженню прийомних дітей; 3) представляти дитину у всіх установах, організаціях; 4) не перешкоджати контакту дитини із соціальним працівником відповідного центру соціальних служб для сім'ї, дітей та молоді; 5) сприяти забезпеченню пріоритетного права прийомних дітей на усиновлення, комунікування з близькими родичами; 6) раціонально витрачати кошти, виділені на утримання дитини, тощо.

Таким чином, спосіб виконання зобов'язань за договором про влаштування дітей-сиріт та дітей, позбавлених батьківського піклування, у прийомну сім'ю визначається умовами договору, загальними положеннями гл. 20-1 СК України, а також спеціально закріпленими правилами Положення про прийомну сім'ю.

Важливим елементом виконання договорів про влаштування дітей-сиріт та дітей, позбавлених батьківського піклування, у прийомну сім'ю є дотримання умов щодо строків їх виконання. За закріпленим у ст. 530 ЦК України загальним правилом зобов'язання повинно бути виконано у визначений умовами договору строк. Екстраполюючи наведене правило у досліджувані нами правовідносини, слід зазначити, що строк, на який укладається договір про влаштування дітей-сиріт та дітей, позбавлених батьківського піклування, у прийомну сім'ю, передбачено на законодавчому рівні ч. 3 ст. 256-3 СК України шляхом вказівки на подію, яка неминуче має настати (досягнення дитиною повноліття, а в разі навчання у професійно-технічних, вищих навчальних закладах I-IV рівнів акредитації - до його закінчення). Як слушно наголошує з цього приводу В.В. Луць, строковою можна назвати ту подію, настання якої $є$ неминучим, на відміну від події, що використовується у разі укладення умовних правочинів і характеризується тим, що вірогідність її настання невідома. Визначаючи ж строк або термін події, яка має неминуче настати, сторони цивільного правовідношення усвідомлюють об'єктивний характер певної події (обставини) і неминучість її настання, хоч і конкретний момент настання цієї події в часі може бути наперед їм невідомим [7, с. 21]. Відповідно, строки, визначені вказівкою на подію, яка неминуче має настати, пропонується відносити до відносно визначених строків [8, с. 48]. Тобто відносно визначені строки характеризуються меншою точністю, однак також пов'язані з певним періодом чи моментом часу. Отже, особливість виконання досліджуваного нами договору щодо строку виконання обов'язків полягає у закріпленні прямої вказівки на строк договору у нормативно-правовому акті, який врегульовуе окремі види відносин з надання послуг. 
Крім того, особливість виконання зобов'язань за договором про влаштування дітей-сиріт та дітей, позбавлених батьківського піклування, у прийомну сім'ю відображається також у діях замовника - уповноваженого органу виконавчої влади, який зобов'язаний щомісячно до 20 числа здійснювати виплати державної соціальної допомоги та грошового забезпечення, адже досліджуваний договір є договором про надання послуг, які за своєю сутністю є такими, що необхідні замовнику постійно. Це означає, що одні і ті ж дії виконавець зобов'язується виконувати впродовж строку, на який укладено договір. Відповідно й замовник зобов'язаний періодично у визначений п. 19 Положення про прийомну сім'ю строк оплачувати отриману на користь прийомної дитини послугу. Більше того, для належного виконання умов договору місцеві відділи у справах сім’ї, дітей та молоді зобов'язані раз на рік забезпечити безкоштовне оздоровлення прийомних дітей у дитячих оздоровчих закладах.

Отже, зважаючи на вищенаведене, можемо констатувати, що особливістю виконання зобов'язань за договором про влаштування дітей-сиріт та дітей, позбавлених батьківського піклування, у прийомну сім'ю $є$ неможливість дострокового надання послуги. Зазначене можна пояснити тим, що надання таких послуг тісно пов'язано з визначеною замовником особою та процесом іï споживання останньою. Тобто в цьому сенсі як прострочення виконання зобов'язання, так і дострокове надання послуги вважатиметься порушенням договірного зобов'язання з надання послуг.

Наступним елементом виконання зобов'язань за договором про влаштування дітей-сиріт та дітей, позбавлених батьківського піклування, у прийомну сім’ю є місце виконання договору. За загальним правилом місцем виконання договорів про надання послуг є місцезнаходження виконавця. Місце виконання може бути визначене законом, договором, або виявлятися зі звичаїв ділового обороту або суті зобов'язання. Пунктом 3 Положення про прийомну сім'ю місцем виконання зобов'язань за досліджуваним договором визначено місце проживання прийомних батьків. Прийомні батьки беруть за плату прийомних дітей на власну житлову площу за наявності відповідних санітарно-гігієнічних та побутових умов (належного стану житлового приміщення, необхідної житлової площі, належного санітарного стану, наявності необхідних меблів, побутової техніки та інших предметів тривалого вжитку, наявності умов для проживання, виховання та розвитку дитини)

3 цього приводу доцільно наголосити, що під місцем проживання фізичної особи зако- нодавець розуміє житло, в якому вона проживає постійно або тимчасово. У ст. 29 ЦК України немає прямої вказівки на те, що таке житло повинно перебувати у неї виключно на праві власності, із чого можемо зробити висновок, що прийомні батьки можуть володіти житлом не лише на праві власності, а й на праві тимчасового володіння й користування ним.

Разом із тим слід звернути увагу, що те місце проживання, яким оперує законодавець у ст. 29 ЦК України, можна вважати певним чином місцем проживання у приватноправовому розумінні. Так, у коментарі до Цивільного кодексу України зазначається, що чинне законодавство містить ще одне, так зване публічноправове, визначення місця проживання, під яке підпадає адміністративно-територіальна одиниця, на території якої особа проживає строком понад шість місяців на рік. Поряд із ним законодавець вводить ще й інше поняття - «місце перебування», під яким розуміється адміністративно-територіальна одиниця, на території якої особа проживає строком менше шести місяців на рік. Відмінність між вказаними поняттями $є$ очевидною. Адже якщо в розумінні ст. 29 ЦК місцем проживання вважається відповідне приміщення, що чітко визначене та має належну поштову адресу, то в публічно-правовому - це є сама адміністративно-територіальна одиниця, тобто АРК, область, район, місто, район у місті, селище чи село, де особа фактично перебуває (місце перебування) [9, с. 66].

Із цього можемо припустити, що місце виконання зобов'язань за договором про влаштування дітей-сиріт та дітей, позбавлених батьківського піклування, у прийомну сім'ю має важливе значення, оскільки у разі переміщення прийомної сім'ї з однієї адміністративно-територіальної одиниці до іншої як у прийомних батьків (виконавців), так i в органу виконавчої влади (замовника) виникає ряд обов'язків щодо: а) повідомлення служби у справах дітей за місцем утворення прийомної сім'ї про намір і причини переміщення; б) письмового звернення служби у справах дітей за місцем утворення прийомної сім'ї до служби у справах дітей за новим місцем функціонування прийомної сім'ї для з'ясування умов іiі проживання на новому місці; в) обстеження житлово-побутових умов прийомної сім'ї та складання акта про це; г) узгодження між службами у справах дітей за місцем утворення прийомної сім'ї та за новим місцем іiї функціонування дати припинення функціонування прийомної сім'ї в одній адміністративно-територіальній одиниці та дати початку їі функціонування в іншій адміністративно-територіальній одиниці; r) прийняття районною, районною у мм. Києві та Севастополі держадміністраціями, вико- 
навчим органом міських, районних у містах (в разі утворення) рад рішення про забезпечення функціонування прийомної сім'ї на відповідній адміністративно-територіальній одиниці.

\section{Висновки}

Отже, на основі вищенаведеного можемо підсумувати, що особливість виконання зобов'язань за договором про влаштування дітей-сиріт та дітей, позбавлених батьківського піклування, у прийомну сім'ю відображається у таких елементах, як: 1) суб'єкти виконання замовник (орган виконавчої влади) і виконавець (прийомні батьки); 2) предмет виконання (дії з надання відповідної послуги та ії оплати); 3) строк виконання (до досягнення 18-річного віку, а в разі навчання у професійно-технічних, вищих навчальних закладах I-IV рівнів акредитації - до його закінчення); 4) місце виконання (місце проживання прийомних батьків); 5) спосіб виконання (пов'язаний 3 педагогічними, освітніми, медичними здібностями прийомних батьків).

\section{Список використаних джерел:}

1. Федорченко Н.В. Договірні зобов'язання 3 надання послуг: проблеми теорії і практики : монографія. Київ, 2015. С. 228-229, 236
2. Лукасевич-Крутник I.С. Теоретичні засади правового регулювання договірних відносин з надання транспортних послуг у цивільному праві України : монографія. Тернопіль: ФОП Паляниця B. A., 2019. C. 316

3. Пленюк М., Коструба А. Юридичні факти в доктрині приватного права України : монографія. Київ : Науково-дослідний інститут приватного права і підприємництва імені академіка Ф.Г. Бурчака НАПрН України, 2018. С. 85.

4. Цивільне право України : підручник : у 2-х кн. Кн. 1. / за ред. О.В. Дзери, Н.С. Кузнєцової. Київ: Юрінком Інтер, 2002. С. 649.

5. Гражданское право : учебник для вузов. Академический курс / отв. ред. М.К. Сулейменов, Ю.Г. Басин. Алма-Аты : КазГЮА, 2000. Т. 1. С. 588

6. Иоффе О.С. Ответственность по советскому гражданскому праву / [Ред. А.К. Юрченко. Ленинград : Изд-во Ленингр. ун-та, 1955. С. 94.

7. Луць В.В. Строки і терміни у цивільному праві : монографія. Київ: Юрінком Інтер, 2013. C. 21.

8. Вахонєва Т.М. Строки (терміни) у цивільному праві : дис. ... канд. юрид. наук: 12.00.03. Київ, 2005. C. 48.

9. Науково-практичний коментар Цивільного кодексу України : у 2 т. 6-те вид., перероб. і допов. / за заг. ред. О.В. Дзери (кер. авт. кол.), Н.С. Кузнєцової, В.В. Луця. Київ: Юрінком Інтер, 2019. T. I. C. 66

The article focuses on the peculiarities of fulfilling the obligations under the agreement on placement of orphans and children deprived of parental care into a foster family. It is emphasized that in accordance with the aforementioned type of agreement, foster parents are not obliged to the ad hoc determination of whether the desirable educational result can be achieved. Moreover, the possibility of achieving the result that might be deemed positive for the child requires the fulfillment of counter-actions as on behalf of the foster parents so by the owner of the services and the child itself, which once again testifies to the complexity of the legal relationships under scrutiny. The execution of this type of contract envisages a continuous involvement of: a) the fosterparents in the process of upbringing; $b$ ) the executive body that provides social support for the foster family.

The peculiarity fulfilling the obligations under the agreement on placement of orphans and children deprived of parental care in a foster family is reflected in such elements as: 1) the subjects of execution the owner of services (executive authority) and the executor (foster parents); 2) the subject of performance (the actions related to the provision of the corresponding service and the remuneration for them); 3 ) the agreement fulfillmenet term (until the child becomes of age, that is 18-year-old, and until graduation in the case of studying in vocational school or higher education establishments of I-IV levels of accreditation); 4) the place of performance (foster parents' place of residence); 5) the method of implementation (related to and depdendent on the pedagogical, educational, and medical abilities of foster parents).

The specifics of the agreement on the placement of orphans and children deprived of parental care into a foster family boils down to bestowing a legislative requirement upon foster parents to provide the defined services personally. In cases like these, the foster parents' identities are essential and that is why the envisaged by the agreement relationships are regulated under Part 1 of Art. 902 of the Civil Code of Ukraine. The peculiarity of performance of the scrutinized type of agreement is equally reflected in the fact that the service is provided not directly to the customer, but to the third party designated by him (an orphan or a child deprived of parental care).

The proper fulfillment of the obligations envisaged by the angreement on placement of orphans and children deprived of parental care in a foster family in regard to the subject is reflected in the provision of proper educational services alongside with observance of the relevant rules and norms pertaining to the conditions of his or her residence, education, food, rest, adoption process, etc. Considering the agreement fulfillment term, the proper fulfillment of obligations boils down to fixing the direct indication of the term of the agreement in a special legal act and the impossibility of early provision of services.

Key words: agreement, foster child, foster family, foster parents, fulfillment of contract conditions, subjects of performance, subject of performance, term of performance, method of performance, place of performance. 